\title{
MENINGKATKAN PERKEMBANGAN BAHASA ANAK DENGAN PERMAINAN MENYAMBUNG CERITA DI KELOMPOK B TK NEGERI O1SANGIR JUJUAN KECAMATAN SANGIR JUJUAN KABUPATEN SOLOK SELATAN
}

\author{
MARDIANIS \\ Guru TK Negeri 01 Sangir Jujuan, Solok Selatan
}

\begin{abstract}
The problem found in this study is that children's language development skills are still low. This happens because the story sequencing games used by the teacher are less interesting in learning, even the children are confused about using them. The choice of language development with inappropriate story-connecting games by the teacher is the cause of this condition and the child is also less satisfying in children's language development with story-connecting games. The purpose of this study was to improve the language development of children in group B TK 01 Sangir Juju, Sangir Junjuk District, South Solok Regency. The subjects of this study were children of group B with 13 children consisting of 6 girls and 7 boys. This type of research is Classroom Action Research (PTK) carried out in two cycles with the stages of each cycle as follows: planning, implementing, observing, reflecting, and documenting, then processed and analyzed by the percentage formula. The benefit of this Classroom Action Research (CAR) is that the ability of children's language development with story-connecting games increases. The results of the study, the average percentage of children's language development abilities can be seen from before the action, to cycle II. Before the action of children's language skills was still low, in the first cycle it began to increase but had not yet reached the KKM. In the second cycle it increased again so that it had exceeded the specified minimum completeness criteria (KKM). Based on the results of the Kelasa Action Research $(C A R)$, it can be concluded that the game of connecting stories in group $B$ has increased, namely the percentage of children's language development in indicator 1 , cycle I 39\% in cycle II increased to $85 \%$, children's language development in indicator 2 , cycle I $54 \%$ in cycle II increases to $77 \%$, children's language development on indicator 3, cycle I 38\%, in cycle II increases to 77\%, and children's language development on indicator 4, cycle I 54\%, in cycle II increases to $69 \%$. In cycle II, children's language development has increased, this can be seen from the results of the scores that have received a lot of BSH and BSB categories. So it can be concluded that this CAR is successful in improving children's language development by connecting games.
\end{abstract}

Keywords: Language, Games, Connecting Stories, Kindergarten.

Abstrak: Permasalahan yang ditemukan dalam penelitian ini adalah kemampuan perkembangan bahasa anak masih rendah. Hal ini terjadi karena permainan menyambung cerita yang digunakan guru kurang menarik dalam pembelajaran, bahkan anak bingung untuk mengunakannya. Pemilihan perkembangan bahasa dengan permainan menyambung cerita yang tidak tepat oleh guru menjadi penyebab terjadinya kondisi ini dan anak juga kurang memuaskan dalam perkembangan bahasa anak dengan permainan menyambung cerita. Tujuan penelitian ini untuk meningkatkan perkembangan bahasa anak di kelompok B TK 01 Sangir Jujuan Kecamatan Sangir Jujuan Kabupaten Solok Selatan. Subjek penelitian ini anak kelompok B dengan 
jumlah anak 13 orang terdiri dari 6 perempuan dan 7 laki-laki. Jenis penelitian ini adalah Penelitian Tindakan Kelas (PTK) dilakukan dalam dua siklus dengan tahapan masing-masing siklus sebagai berikut: perencanaan, pelaksanaan, pengamatan, refleksi, dan dokumentasi, kemudian diolah dan di analisis dengan rumus persentase. Manfaat Penelitian Tindakan Kelas (PTK) ini adalah agar kemampuan perkembangan bahasa anak dengan permainan menyambung cerita meningkat. Hasil penelitian ratarata persentase kemampuan perkembangan bahasa anak dapat dilihat dari sebelum tindakan, sampai siklus II. Sebelum tindakan kemampuan bahasa anak masih rendah, pada siklus I mulai meningkat namun belum mencapai KKM. Pada siklus II meningkat lagi sehingga sudah melebihi Kriteria Ketuntasan Minimal ( KKM) yang ditetapkan. Berdasarkan hasil Penelitian Tindakan Kelasa (PTK) dilakukan dapat disimpulkan bahwa permainan menyambung cerita di kelompok B terjadi peningkatan, yaitu persentase perkembangan bahasa anak pada indikator 1, siklus I 39\% pada siklus II meningkat menjadi $85 \%$, perkembangan bahasa anak pada indikator 2, siklus I $54 \%$ pada siklus II meningkat menjadi $77 \%$, perkembangan bahasa anak pada indikator 3 , siklus I 38\%, pada siklus II meningkat menjadi 77\%, dan perkembangan bahasa anak pada indikator 4, siklus I $54 \%$, pada siklus II meningkat menjadi 69\%. Pada siklus II perkembangan bahasa anak sudah meningkat, ini dapat dilihat dari hasil nilai yang sudah banyak mendapatkan kategori BSH dan BSB. Sehingga dapat disimpulkan bahwa PTK ini berhasil meningkatkan perkembangan bahasa anak dengan permainan menyambung.

Kata kunci: Bahasa, Permainan, Menyambung Cerita, TK.

\section{A. Pendahuluan}

Anak usia empat, lima atau enam tahun mendapat tempat untuk mengembangkan potensi-potensi yang dimilikinya dalam berbagai bentuk kegiatan pembelajaran sambil bermain. Masa keemasan bagi anak dimana segenap aspek perkembangan mengambil peran penting bagi pertumbuhan anak selanjutnya.Agus Wibowo (2012 : 25). Peraturan Menteri no 58 tahun 2009 juga menjelaskan betapa pentingnya memperhatikan pendidikan anak usia dini. Sehingga dalam peraturan menteri tersebutdijelaskan tentang standar pencapaian yang harus dilaksanakan oleh guru-guru pendidikan anak usia dini dalam usaha mengembangkan 5aspek pengembangan. Aspek yang perlu dikembangkan tersebut diantaranya adalah: Nilai-nilai Agama dan Moral; Sosial Emosional dan Kemandirian; Fisik Motorik; Bahasa, dan Kognitif.

Masa-masa emas anak merupakan masa memberikan pendidikan yang tepat bagi anak, sebagaimana tertulis dalam pasal 1 Butir 14 Undang -Undang No.20 tahun 2003 tentang Sistem Pendidikan Nasional, menyebutkan bahwa :"Pendidikan Anak Usia Dini merupakan suatu upaya yang ditujukan kepada anak sejak lahir hingga usia enam tahun yang dilakukan melalui pemberian rangsangan pendidikan untuk membantu pertumbuhan dan perkembangan jasmani dan rohani agar anak memiliki kesiapan untuk memasuki jenjang pendidikan lebih lanjut. Bahasa memegang peranan penting dalam kehidupan manusia karena bahasa merupakan alat komunikasi manusia dalam kehidupan sehari-hari. Dengan bahasa, seorang dapat menyampaikan ide, pikiran, perasaan kepada orang lain, baik secara lisan maupun tulisan. Hal ini sejalan dengan pendapat B. Keraf (2004 : 1), bahwa bahasa adalah alat komunikasi antar anggota masyarakat berupa simbol bunyi yang dihasilkan oleh alat ucap manusia. Pengembangan bahasa di TK ialah usaha atau kegiatan mengembangkan perkembangan anak untuk berkomunikasi dengan lingkungannya melalui bahasa. 
Bahasa dipergunakan pada sebagian besar aktivitas manusia, tanpa bahasa manusia tidak dapat menggungkapkan perasaannya, menyampaikan keinginan, memberikan saran dan pendapat, bahkan sampai tingkat pemikiran seseorang yang berkaitan dengan bahasa. Semakin tinggi tingkat penguasaan bahasa seseorang, semakin baik pula penggunaan bahasa dalam berkomunikasi. Manusia dalam mengungkapkan bahasanyapun berbeda-beda, ada yang lebih suka langsung menbicarakannya dan ada juga lebih suka melalui tulisan. Berbicara termasuk pengembangan bahasa yang merupakan salah satu bidang yang perlu dikuasai anak usia dini. Pada masa ini anak usia dini memerlukan berbagai rangsangan yang dapat meningkatkan perkembangan bahasa anak, sehingga dengan pemberian rangsangan yang tepat maka bahasa anak dapat tercapai secara optimal.

Keterampilan bahasa mempunyai empat komponen yang terdiri dari keterampilan menyimak, keterampilan berbicara, keterampilan membaca, dan keterampilan menulis. Keempat keterampilan tersebut memiliki hubungan yang saling terkait satu sama lain, yang merupakan satu kesatuan. Keempat keterampilan tersebut perlu dilatih pada anak usia dini karena dengan perkembangan bahasa tersebut anak akan belajar berkomunikasi dengan orang lain. Sebagaimana dalam kurikulum 2004 diungkapkan bahwa kompetensi dasar dari pengembangan bahasa untuk anak usia dini yaitu "anak mampu mendengarkan, berkomunikasi secara lisan, memiliki perbendaharaan kata dan mengenal simbol-simbol yang melambangkannya". Salah satu masalah yang berkaitan dengan bahasa pada anak usia dini adalah Permasalahan yang timbul di kelompok B TK Negeri 01 Sangir Jujuan yaitu kurang mendapatkan perhatian dari pengajar,karena guru lebih memfokuskan pada menggembangkan kognitif. Akibatnya perbendaharaan kata yang dimiliki anak usia dini masih terbatas,sehingga anak usia dini kurang mahir dalam menggunakan bahasa untuk bercerita maupun menggungkapkan ide-ide ataupun gagasan.

Metode yang dapat digunakan untuk pengembangan bahasa anak adalah dengan bermain dan dengan merangsang anak untuk berbahasa yaitu bercerita. Metode bercerita cara bertutur kata dan menyampaikan cerita atau memberikan penerangan secara lisan, metode tersebut dapat melatih anak terbiasa untuk dapat mengungkapkan persaaannya lewat bahasa lisan dan anak dapat termotivasi untuk terampil mengungkapkan perasaannya di depan kelas tanpa malu-malu. Berdasarkan kenyataan tersebut peneliti melihat penelitian ini perlu untuk dilakukan. Kemampuan bahasa anak dapat peneliti ketahui dan teliti. Selain itu peneliti ingin mengetahui adakah peningkatan perkembangan bahasa anak dan pemahaman anak. Untuk mewujudkan hal tersebut penulis gunakan permainan menyambung cerita. Media ini di anggap mampu dan dapat untuk pelaksanaan pembelajaran perkembangan bahasa anak di kelompok B TK Negeri 01 Sangir Jujan Kecamatan Sangir Jujuan Kabupaten Solok Selatan. Rendahnya perkembangan bahasa anak dapat dilihat dari data berikut:

Tabel 1

Observasi Awal Perkembangan Bahasa Anak kelompok B TK Negeri 01 Sangir Jujan Kecamatan Sangir Jujuan Kabupaten Solok Selatan

\begin{tabular}{|l|l|c|c|c|c|}
\hline No & Nama & \multicolumn{4}{|c|}{ Indikator Perkembangan Bahasa Anak } \\
\cline { 2 - 6 } & $\begin{array}{c}\text { Mendengarkan } \\
\text { Cerita dengan } \\
\text { Penuh Perhatian }\end{array}$ & $\begin{array}{c}\text { Melanjutkan/ } \\
\text { menyambung } \\
\text { kembali cerita } \\
\text { yang telah } \\
\text { didengar }\end{array}$ & $\begin{array}{c}\text { Mengulang } \\
\text { kalimat yang } \\
\text { telah didengar }\end{array}$ & $\begin{array}{c}\text { Berani } \\
\text { bertanya secara } \\
\text { sederhana }\end{array}$ \\
\hline
\end{tabular}




\begin{tabular}{|c|c|c|c|c|c|c|c|c|c|c|c|c|c|c|c|c|c|}
\hline & & BB & MB & BSH & BSF & BB & MB & BSH & BSB & $\mathbf{B B}$ & MB & BSF & $\mathbf{B S}$ & BB & MI & BSI & BSE \\
\hline 1 & $\mathrm{AFH}$ & $\checkmark$ & & & & $\checkmark$ & & & & $\checkmark$ & & & & $\checkmark$ & & & \\
\hline 2 & AA & $\checkmark$ & & & & & $\checkmark$ & & & $\checkmark$ & & & & $\checkmark$ & & & \\
\hline 3 & $\mathrm{AO}$ & & $\checkmark$ & & & & $\checkmark$ & & & & & $\checkmark$ & & & $\checkmark$ & & \\
\hline 4 & AANQ & & $\checkmark$ & & & & $\checkmark$ & & & & & $\checkmark$ & & $\checkmark$ & & & \\
\hline 5 & APS & & & $\checkmark$ & & & $\sqrt{ }$ & & & & $\checkmark$ & & & & $\sqrt{ }$ & & \\
\hline 6 & $\mathrm{AH}$ & $\checkmark$ & & & & $\checkmark$ & & & & $\checkmark$ & & & & $\checkmark$ & & & \\
\hline 7 & $\mathrm{AS}$ & & $\checkmark$ & & & & $\checkmark$ & & & & $\checkmark$ & & & & $\checkmark$ & & \\
\hline 8 & ADA & & & $\checkmark$ & & $\checkmark$ & & & & $\checkmark$ & & & & $\checkmark$ & & & \\
\hline 9 & $\mathrm{AD}$ & & $\sqrt{ }$ & & & & & $\checkmark$ & & & $\sqrt{ }$ & & & $\checkmark$ & & & \\
\hline 10 & AZR & $\sqrt{ }$ & & & & & & $\checkmark$ & & & $\checkmark$ & & & & $\checkmark$ & & \\
\hline 11 & AHY & $\checkmark$ & & & & $\checkmark$ & & & & $\checkmark$ & & & & & & $\checkmark$ & \\
\hline 12 & $\mathrm{AB}$ & & $\checkmark$ & & & & $\checkmark$ & & & & $\checkmark$ & & & & & $\checkmark$ & \\
\hline 13 & AFR & $\checkmark$ & & & & $\checkmark$ & & & & $\checkmark$ & & & & & $\checkmark$ & & \\
\hline $\begin{array}{c}\text { JM } \\
\text { L }\end{array}$ & 13 & 6 & 5 & 2 & 0 & 5 & 6 & 2 & 0 & 6 & 5 & 2 & 0 & 6 & 5 & 2 & $\mathbf{0}$ \\
\hline & $\%$ & 46 & 39 & 15 & 0 & 39 & 46 & 15 & 0 & 46 & 39 & 15 & 0 & 46 & 39 & 15 & 0 \\
\hline
\end{tabular}

Sumber data: Buku penilaian guru tahun 2015/2016

Ket Penilaian:
BB Belum Berkembang
MB Mulai Berkembang
BSH Berkembang Sesuai Harapan
BSB Berkembang Sangat Baik

Dari data observasi awal terlihat masih rendahnya perkembangan bahasa anak kelompok B TK Negeri 01 Sangir Jujuan. Hal ini terbukti bahwa persentase BSH hanya $15 \%$. Sedangkan pada indikator lainnya juga masih belum terlihat perkembangan bahasa anak. Hal ini terjadi di semua indikator yang dinilai. Kenyataan ini tentu merupakan masalah yang harus dipecahkan oleh guru TK Negeri 01 Sangir Jujuan Kecamatan sangir jujuan artinya perkembangan bahasa anak harus mendapat perhatian agar anak mampu mengembangkan dirinya kepada yang lebih baik. Berdasarkan latar belakang dan masalah tersebut, peneliti merasa tertarik untuk meneliti tentang "Meningkatkan perkembangan bahasa anak melalui permainan menyambung cerita di kelompok B TK Negeri 01 Sangir Jujuan Kecamatan sangir jujuan Kabupaten Solok Selatan".

\section{B. Metodologi Penelitian}

Menurut Arikunto (2008:16) "Penelitian Tindakan Kelas (PTK) merupakan suatu pencermatan terhadap kegiatan belajar berupa sebuah tindakan yang sengaja dimunculkan dan terjadi dalam sebuah kelas secara bersama”. PTK ini dilakukan pada semester II di kelompok TK Negeri 01 Sangir Jujuan Kecamatan Sangir Jujuan Kabupaten Solok Selatan dengan jumlah anak 13 orang yang terdiri dari 7 laki-laki dan 6 perempuan. Alur penelitian adalah langkah-langkah yang harus dilakukan pada tiap bagian dalam suatu penelitian tindakan kelas. Menurut Suharsimi Arikunto (2008:16) ada 4 tahapan yang dipakai dalam penelitian tindakan kelas yaitu; (1) perencanaan, (2) pelaksanaan, (3) pengamatan, dan (4) refleksi. Data penelitian ini berupa hasil lembaran pengamatan dan dokumentasi dari setiap tindakan pada pembelajaran bermain sambil belajar pada anak di kelompok B TK Negeri 01 Sangir Jujuan Kecamatan Sangir Jujuan Kabupaten Solok Selatan. Sumber data penelitian ini adalah 
proses kegiatan pembelajaran yang dilakukan pada anak di kelompok TK Negeri 01 Sangir Jujuan Kecamatan Sangir Jujuan Kabupaten Solok Selatan. Teknik Pengumpulan Data yang digunakan yaitu menggunakan Lembar Observasi dan Dokumentasi. Sedangkan untuk Teknik Analisis Data yang digunakan dari hasil perkembangan bahasa anak diolah dengan teknik persentase dengan menggunakan rumus yang dikemukakan oleh Sudijono (2006:43) sebagai berikut :

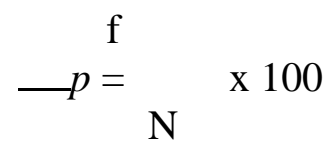

Keterangan :

$$
\begin{aligned}
& \mathrm{f}=\text { frekuensi yang sedang dicari persentasenya. } \\
& \mathrm{N}=\text { Number of Cases (jumlah frekuensi/banyaknya individu). } \\
& \mathrm{P}=\text { angka persentase }
\end{aligned}
$$

Hasil analisis ini digunakan untuk refleksi dalam menyusun tindakan selanjutnya dan diakhir penulisan akan dijadikan kesimpulan penulisan. Berdasarkan penelitian yang telah dilakukan, maka penelitian ini dikatakan berhasil apabila perkembangan bahasa anak telah meningkat melalui permainan menyambung cerita dengan kategori persentase kemampuan anak mencapai $75 \%$ atau lebih yang sesuai dengan standar yang dikeluarkan oleh Badan Standar Nasional Pendidikan (BSNP).

\section{Hasil dan Pembahasan}

Penelitian ini dilakukan dengan dua siklus dan masing - masing siklus terdiri dari dua kali pertemuan. Siklus I dilaksanakan 2 kali pertemuan. Data Hasil Pengamatan Perkembangan bahasa Anak Melalui dengan permainan Menyambung Cerita di Kelompok B TK Negeri 01 Sangir Jujuan Kecamatan Sangir Jujuan Kabupaten Solok Selatan pada siklus I Pertemuan I yaitu pada Tabel dibawah ini :

\section{Tabel 2}

Data Hasil Pengamatan Perkembangan bahasa Anak Melalui dengan permainan

\begin{tabular}{|c|c|c|c|c|c|c|c|c|c|c|c|c|c|c|c|c|c|}
\hline \multirow{3}{*}{ No } & \multirow{3}{*}{$\begin{array}{l}\text { Kode } \\
\text { Nama }\end{array}$} & \multicolumn{16}{|c|}{$\begin{array}{c}\text { Indikator Perkembangan } \\
\text { Bahasa Anak }\end{array}$} \\
\hline & & \multicolumn{4}{|c|}{1} & \multicolumn{4}{|c|}{2} & \multicolumn{4}{|c|}{$\mathbf{3}$} & \multicolumn{4}{|c|}{4} \\
\hline & & BB & MB & $\begin{array}{l}\text { BS } \\
\mathbf{H}\end{array}$ & BSB & BB & MB & $\begin{array}{l}\text { BS } \\
\text { H }\end{array}$ & $\begin{array}{l}\text { BS } \\
\text { B }\end{array}$ & BB & MB & $\begin{array}{l}\text { BS } \\
\mathrm{H}\end{array}$ & $\begin{array}{l}\text { BS } \\
\text { B }\end{array}$ & BB & MB & $\begin{array}{l}\text { BS } \\
\mathbf{H}\end{array}$ & $\begin{array}{l}\text { BS } \\
\text { B }\end{array}$ \\
\hline 1 & $\mathrm{AFH}$ & & & & $\checkmark$ & & & $\sqrt{ }$ & & & & & $\sqrt{ }$ & $\checkmark$ & & & \\
\hline 2 & AA & & $\checkmark$ & & & & & $\sqrt{ }$ & & & $\checkmark$ & & & $\checkmark$ & & & \\
\hline 3 & $\mathrm{AO}$ & & & & $\checkmark$ & & & & $\checkmark$ & 1 & & $\checkmark$ & 1 & & $\checkmark$ & & \\
\hline 4 & AANQ & $\checkmark$ & & & & & & & $\sqrt{ }$ & & & & $\sqrt{ }$ & & & & \\
\hline 5 & APS & & & $\checkmark$ & & & $\sqrt{ }$ & & & & $\checkmark$ & & & & $\checkmark$ & & \\
\hline 6 & $\mathrm{AH}$ & & $\checkmark$ & & & $\checkmark$ & & & & & & $\checkmark$ & & $\checkmark$ & & & \\
\hline 7 & AS & & $\checkmark$ & & & & $\checkmark$ & & & & $\checkmark$ & 1 & & & $\checkmark$ & & \\
\hline 8 & $\mathrm{ADA}$ & $\checkmark$ & & & & $\sqrt{ }$ & & & & $\sqrt{ }$ & & & & & $\checkmark$ & & \\
\hline 9 & $\mathrm{AD}$ & & $\checkmark$ & & & & & $\sqrt{ }$ & & $\checkmark$ & & & & & & $\checkmark$ & \\
\hline 10 & AZR & & & & $\checkmark$ & & & $\sqrt{ }$ & & $\checkmark$ & & & & & & $\sqrt{ }$ & \\
\hline 11 & AHY & & $\checkmark$ & & & & & & $\sqrt{ }$ & & & & $\checkmark$ & & & & $\checkmark$ \\
\hline
\end{tabular}
Menyambung Cerita di Kelompok B TK Negeri 01 Sangir Jujuan Kecamatan Sangir Jujuan Kabupaten Solok Selatan pada siklus I Pertemuan I 


\begin{tabular}{|l|c|c|c|c|c|c|c|c|c|c|c|c|c|c|c|c|c|}
\hline 12 & $\mathrm{AB}$ & & $\checkmark$ & & & & $\checkmark$ & & & & $\checkmark$ & & & & $\checkmark$ & & \\
\hline 13 & AFR & & & & $\checkmark$ & $\checkmark$ & & & & $\checkmark$ & & & & & & $\checkmark$ & \\
\hline & Jml & $\mathbf{2}$ & $\mathbf{6}$ & $\mathbf{1}$ & $\mathbf{4}$ & $\mathbf{3}$ & $\mathbf{3}$ & $\mathbf{4}$ & $\mathbf{3}$ & $\mathbf{4}$ & $\mathbf{4}$ & $\mathbf{2}$ & $\mathbf{3}$ & $\mathbf{3}$ & $\mathbf{5}$ & 3 & $\mathbf{2}$ \\
\hline
\end{tabular}

Ket Penilaian:

BB Belum Berkembang

MB Mulai Berkembang

BSH Berkembang Harapan
1 Mendengarkan cerita dengan penuh perhatian

2 Melanjutkan/ Menyambung sebagian cerita yang telah didengarnya

Sesuai 3 Mengulang kalimat yang telah didengar

4 Berani bertanya secara sederhana

Dari hasil penelitian Siklus I Pertemuan I maka Perkembangan bahasa anak belum mencapai KKM yang ditetapkan sebesar $75 \%$. Penelitian ini dilanjutkan pada siklus I pertemuan II karena belum mencapai indikator keberhasilan. Data Hasil Pengamatan Perkembangan bahasa Anak Melalui dengan permainan Menyambung Cerita di Kelompok B TK Negeri 01 Sangir Jujuan Kecamatan Sangir Jujuan Kabupaten Solok Selatan pada siklus I Pertemuan II yaitu pada Tabel dibawah ini :

Tabel 3

Data Hasil Pengamatan Perkembangan Bahasa Anak dengan Permainan Menyambung Cerita di Kelompok B TK Negeri 01Sangir Jujuan

Pada Siklus I Pertemuan II

\begin{tabular}{|c|c|c|c|c|c|c|c|c|c|c|c|c|c|c|c|c|c|}
\hline \multirow{3}{*}{ No } & \multirow{3}{*}{$\begin{array}{c}\text { Nama } \\
\text { anak }\end{array}$} & \multicolumn{16}{|c|}{$\begin{array}{c}\text { Indikator Perkembangan } \\
\text { Bahasa Anak }\end{array}$} \\
\hline & & \multicolumn{4}{|c|}{1} & \multicolumn{4}{|c|}{2} & \multicolumn{4}{|c|}{$\mathbf{3}$} & \multicolumn{4}{|c|}{4} \\
\hline & & $\begin{array}{l}\text { B } \\
\text { B }\end{array}$ & $\begin{array}{l}\mathbf{M} \\
\mathbf{B}\end{array}$ & $\begin{array}{l}\text { B } \\
\text { S } \\
\mathbf{H}\end{array}$ & $\begin{array}{l}\text { B } \\
\text { S } \\
\text { B }\end{array}$ & $\begin{array}{l}\text { B } \\
\text { B }\end{array}$ & $\begin{array}{l}\text { M } \\
\mathbf{B}\end{array}$ & $\begin{array}{l}\text { B } \\
\text { S } \\
\mathbf{H}\end{array}$ & $\begin{array}{l}\text { B } \\
\text { S } \\
\text { B }\end{array}$ & $\begin{array}{l}\text { B } \\
\text { B }\end{array}$ & $\begin{array}{l}\mathbf{M} \\
\mathbf{B}\end{array}$ & $\begin{array}{l}\text { B } \\
\text { S } \\
\text { H }\end{array}$ & $\begin{array}{l}\text { B } \\
\text { S } \\
\text { B }\end{array}$ & $\begin{array}{l}\text { B } \\
\text { B }\end{array}$ & $\begin{array}{l}\mathbf{M} \\
\mathbf{B}\end{array}$ & $\begin{array}{l}\text { B } \\
\text { S } \\
\mathbf{H}\end{array}$ & $\begin{array}{l}\text { B } \\
\text { S } \\
\text { B }\end{array}$ \\
\hline 1 & AFH & & & & $\sqrt{ }$ & $\sqrt{ }$ & & & & & & $\checkmark$ & & $\checkmark$ & & & \\
\hline 2 & AA & & & $\checkmark$ & & & & & $\checkmark$ & & & & $\sqrt{ }$ & $\checkmark$ & & & \\
\hline 3 & $\mathrm{AO}$ & & $\checkmark$ & & & & $\checkmark$ & & & & & $v$ & & & & & $\sqrt{ }$ \\
\hline 4 & AANQ & & $\checkmark$ & & & & & $\checkmark$ & & & & $v$ & & & & & $\sqrt{ }$ \\
\hline 5 & APS & & & $\checkmark$ & & $v$ & & & & & & & $\sqrt{ }$ & & $\checkmark$ & & \\
\hline 6 & $\mathrm{AH}$ & & & $\checkmark$ & & & & & $v$ & & & $\checkmark$ & & $\checkmark$ & & & \\
\hline 7 & AS & & & $\checkmark$ & & $\checkmark$ & & & & & & & $\sqrt{ }$ & & & & $\sqrt{ }$ \\
\hline 8 & $\mathrm{ADA}$ & & & $\checkmark$ & & & & $\checkmark$ & & $\checkmark$ & & & & & & & $\sqrt{ }$ \\
\hline 9 & $\mathrm{AD}$ & & $\checkmark$ & & & & & & $v$ & & & & $\sqrt{ }$ & & & $\checkmark$ & \\
\hline 10 & AZR & & & & $\checkmark$ & & & $\checkmark$ & & $\checkmark$ & & & & & & $\checkmark$ & \\
\hline 11 & AHY & & & & $\checkmark$ & & & $\checkmark$ & & & & & 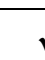 & & $\checkmark$ & & \\
\hline 12 & $\mathrm{AB}$ & & & & $\checkmark$ & & $v$ & & & & $\checkmark$ & & & & $\checkmark$ & & \\
\hline 13 & AFR & & & & $\checkmark$ & & & $\checkmark$ & & $v$ & & & & $\checkmark$ & & & \\
\hline & Jml & 0 & 3 & 5 & 5 & 3 & 2 & 5 & 3 & 3 & 1 & 4 & 5 & 4 & 3 & 2 & 4 \\
\hline
\end{tabular}


Ket Penilaian:
BB Belum Berkembang
1 Mendengarkan cerita dengan penuh
MB Mulai Berkembang
2 Melanjutkan/ Menyambung sebagian cerita yang telah di dengarkan
BSH Berkembang Sesuai 3 Mengulang kalimat yang telah didengar Harapan
BSB Berkembang Sangat Baik 4 Berani bertanya secara sederhana

Berdasarkan hasil penelitian pada siklus I dapat dilihat perkembangan bahasa anak dengan permainan menyambung cerita pada pertemuan I dan pertemuan II sudah mulai meningkat namun belum mencapai indikator keberhasilan. Untuk lebih jelasnya dapat dlihat pada grafik 1:

\section{Grafik 1}

Meningkatkan Perkembangan Bahasa Anak dengan Permainan Menyambung cerita di Kelompok B

TK Negeri 01 Sangir jujuan Kecamatan Sangir Jujuan Kabupaten Solok Selatan

\section{Nilai rata-rata siklus I Pertemuan I dan II BSH+BSB}

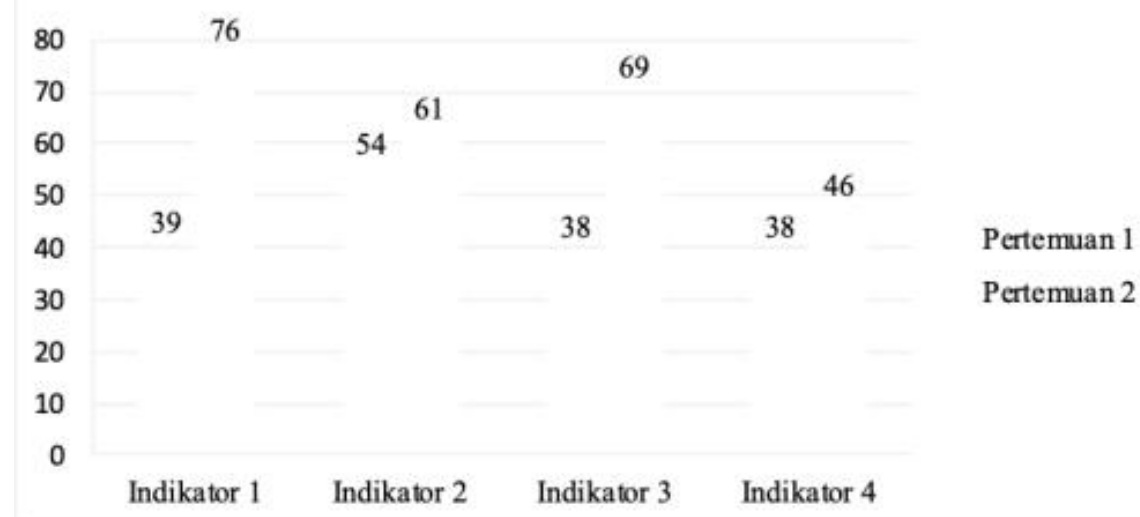

Siklus II juga dilaksanakan 2 kali pertemuan. Data Hasil Pengamatan Perkembangan bahasa Anak Melalui dengan permainan Menyambung Cerita di Kelompok B TK Negeri 01 Sangir Jujuan Kecamatan Sangir Jujuan Kabupaten Solok Selatan pada siklus II Pertemuan I yaitu pada Tabel dibawah ini :

\section{Tabel 4}

Data Hasil Pengamatan Perkembangan Bahasa Anak Dengan Permainan Menyambung Cerita di Kelompok B

\begin{tabular}{|c|c|c|c|c|c|c|c|c|c|c|c|c|c|c|c|c|c|}
\hline \multirow{4}{*}{ NO } & \multicolumn{17}{|c|}{ TK Negeri 01Sangir JujuanSiklus II Pertemuan I } \\
\hline & \multirow{3}{*}{$\begin{array}{l}\text { Kode } \\
\text { Nama }\end{array}$} & \multicolumn{16}{|c|}{$\begin{array}{c}\text { Indikator Perkembangan } \\
\text { Bahasa Anak }\end{array}$} \\
\hline & & \multicolumn{4}{|c|}{1} & \multicolumn{4}{|c|}{2} & \multicolumn{4}{|c|}{3} & \multicolumn{4}{|c|}{4} \\
\hline & & $\begin{array}{l}\text { B } \\
\text { B }\end{array}$ & $\begin{array}{l}\mathbf{M} \\
\mathbf{B}\end{array}$ & $\begin{array}{c}\text { B } \\
\mathbf{S} \\
\mathbf{H}\end{array}$ & $\begin{array}{l}\text { B } \\
\text { S } \\
\text { B }\end{array}$ & $\begin{array}{l}\text { B } \\
\text { B }\end{array}$ & $\begin{array}{l}\text { M } \\
\mathbf{B}\end{array}$ & $\begin{array}{c}\text { B } \\
\mathbf{S} \\
\mathbf{H}\end{array}$ & $\begin{array}{l}\text { B } \\
\text { S } \\
\text { B }\end{array}$ & $\begin{array}{l}\text { B } \\
\text { B }\end{array}$ & $\begin{array}{l}\mathbf{M} \\
\mathbf{B}\end{array}$ & $\begin{array}{c}\text { B } \\
\mathbf{S} \\
\mathbf{H}\end{array}$ & $\begin{array}{l}\text { B } \\
\text { S } \\
\text { B }\end{array}$ & $\begin{array}{l}\text { B } \\
\text { B }\end{array}$ & $\begin{array}{l}\mathbf{M} \\
\mathbf{B}\end{array}$ & $\begin{array}{c}\mathbf{B} \\
\mathbf{S} \\
\mathbf{H}\end{array}$ & $\begin{array}{l}\text { B } \\
\text { S } \\
\text { B }\end{array}$ \\
\hline 1 & $\mathrm{AFH}$ & & & & $\sqrt{ }$ & & & $\checkmark$ & & & & & $\checkmark$ & $\sqrt{ }$ & & & \\
\hline 2 & AA & & & & $\sqrt{ }$ & & $\checkmark$ & & & & $\checkmark$ & & & & & $\checkmark$ & \\
\hline 3 & $\mathrm{AO}$ & & & $\checkmark$ & & & & & $\checkmark$ & & & $\sqrt{ }$ & & & & & $\sqrt{ }$ \\
\hline
\end{tabular}




\begin{tabular}{|c|c|c|c|c|c|c|c|c|c|c|c|c|c|c|c|c|c|}
\hline 4 & AANQ & & $\checkmark$ & & & & & & $\checkmark$ & & $\checkmark$ & & & & & $\checkmark$ \\
\hline 5 & APS & & & $\checkmark$ & & & & $\checkmark$ & & & $\checkmark$ & & & & $\checkmark$ & & \\
\hline 6 & AH & & & $\checkmark$ & & & & & $\checkmark$ & & & $\checkmark$ & & & & $\checkmark$ & \\
\hline 7 & AS & & & $\checkmark$ & & & $\checkmark$ & & & & & $\checkmark$ & & & $\checkmark$ & & \\
\hline 8 & ADA & & & $\checkmark$ & & & & $\checkmark$ & & $\checkmark$ & & & & & & $\checkmark$ & \\
\hline 9 & AD & & & $\checkmark$ & & & & & $\checkmark$ & & & $\checkmark$ & & & & $\checkmark$ & \\
\hline 10 & AZR & & $\checkmark$ & & & & & $\checkmark$ & & & & $\checkmark$ & & & & $\checkmark$ & \\
\hline 11 & AHY & & & & $\sqrt{ }$ & & & & $\checkmark$ & & & & $\checkmark$ & & & & $\checkmark$ \\
\hline 12 & AB & & & $\checkmark$ & & $\checkmark$ & & & & & $\checkmark$ & & & $\checkmark$ & & \\
\hline 13 & AFR & & & & $\sqrt{2}$ & & & & $\checkmark$ & & & & $\checkmark$ & & & & $\checkmark$ \\
\hline JML & $\mathbf{1 3}$ & $\mathbf{0}$ & $\mathbf{2}$ & $\mathbf{7}$ & $\mathbf{4}$ & $\mathbf{0}$ & $\mathbf{3}$ & $\mathbf{4}$ & $\mathbf{6}$ & $\mathbf{1}$ & $\mathbf{2}$ & $\mathbf{7}$ & $\mathbf{3}$ & $\mathbf{1}$ & $\mathbf{3}$ & $\mathbf{5}$ & $\mathbf{4}$ \\
\hline
\end{tabular}

Ket Penilaian:
BB Belum Berkembang
1 Mendengarkan cerita dengan penuh perhatian
MB Mulai Berkembang
2 Melanjutkan/ Menyambung sebagian cerita yang telah didengarnya
BSH Berkembang Sesuai Harapan 3 Mengulang kalimat yang telah didiengar
BSB Berkembang Sangat Baik 4 Berani bertanya secara sederhana

Sedangkan Data Hasil Pengamatan Perkembangan bahasa Anak Melalui dengan permainan Menyambung Cerita di Kelompok B TK Negeri 01 Sangir Jujuan Kecamatan Sangir Jujuan Kabupaten Solok Selatan pada siklus II Pertemuan II yaitu pada Tabel dibawah ini :

Tabel 5

Data Hasil Pengamatan Perkembangan bahasa Anak Dengan permainan menyambung ceita pada siklus II Pertemuan II

\begin{tabular}{|c|c|c|c|c|c|c|c|c|c|c|c|c|c|c|c|c|c|}
\hline \multirow{3}{*}{ NO } & \multirow{3}{*}{$\begin{array}{l}\text { Kode } \\
\text { Nama }\end{array}$} & \multicolumn{16}{|c|}{$\begin{array}{c}\text { Indikator Perkembangan } \\
\text { Bahasa Anak }\end{array}$} \\
\hline & & \multicolumn{4}{|c|}{1} & \multicolumn{4}{|c|}{2} & \multicolumn{4}{|c|}{3} & \multicolumn{4}{|c|}{4} \\
\hline & & $\begin{array}{l}\text { B } \\
\mathbf{B}\end{array}$ & $\begin{array}{l}\text { M } \\
\mathbf{B}\end{array}$ & $\begin{array}{l}\mathbf{B} \\
\mathbf{S} \\
\mathbf{H}\end{array}$ & $\begin{array}{l}\text { B } \\
\text { S } \\
\text { B }\end{array}$ & $\begin{array}{l}\text { B } \\
\text { B }\end{array}$ & $\begin{array}{c}\text { M } \\
\mathbf{B}\end{array}$ & $\begin{array}{l}\mathbf{B} \\
\mathbf{S} \\
\mathbf{H}\end{array}$ & $\begin{array}{l}\text { B } \\
\text { S } \\
\text { B }\end{array}$ & $\begin{array}{l}\text { B } \\
\text { B }\end{array}$ & $\begin{array}{l}\mathbf{M} \\
\mathbf{B}\end{array}$ & $\begin{array}{l}\text { B } \\
\text { S } \\
\mathbf{H}\end{array}$ & $\begin{array}{l}\text { B } \\
\text { S } \\
\text { B }\end{array}$ & $\begin{array}{l}\text { B } \\
\text { B }\end{array}$ & $\begin{array}{c}\text { M } \\
\text { B }\end{array}$ & $\begin{array}{c}\mathbf{B} \\
\mathbf{S} \\
\mathbf{H}\end{array}$ & $\begin{array}{l}\mathbf{B} \\
\mathbf{S} \\
\mathbf{B}\end{array}$ \\
\hline 1 & AFH & & & $\sqrt{ }$ & & & $\checkmark$ & & & & & & $\checkmark$ & & $\checkmark$ & & \\
\hline 2 & $\mathrm{AA}$ & & & & $\sqrt{ }$ & & & & $\checkmark$ & & & $\sqrt{ }$ & & & & & $\checkmark$ \\
\hline 3 & $\mathrm{AO}$ & & & $\sqrt{ }$ & & & & & $\checkmark$ & & & $\sqrt{ }$ & , & 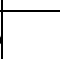 & $\checkmark$ & & \\
\hline 4 & AANQ & & $\sqrt{ }$ & & & & $\checkmark$ & & & & & $\sqrt{ }$ & , & 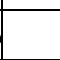 & & $\sqrt{ }$ & \\
\hline 5 & APS & & & $\sqrt{ }$ & & & & $\sqrt{ }$ & & & & $\checkmark$ & & & & $\checkmark$ & \\
\hline 6 & $\mathrm{AH}$ & & & $\sqrt{ }$ & & & & & $\checkmark$ & & $\checkmark$ & & & & & $\checkmark$ & \\
\hline 7 & AS & & & $\checkmark$ & & & & $\sqrt{ }$ & & & & & $\checkmark$ & & & $\checkmark$ & \\
\hline 8 & ADA & & & $\sqrt{ }$ & & & & $\sqrt{ }$ & & & & $\checkmark$ & & & & $\checkmark$ & \\
\hline 9 & $\mathrm{AD}$ & & & $\sqrt{ }$ & & & & & $\sqrt{ }$ & & & & $\checkmark$ & & & & $\checkmark$ \\
\hline 10 & AZR & & $\sqrt{ }$ & & & & & $\sqrt{ }$ & & $\checkmark$ & & & & & & & $\sqrt{ }$ \\
\hline 11 & AHY & & & & $\sqrt{ }$ & & & & $\checkmark$ & & & & $\checkmark$ & & & & $\checkmark$ \\
\hline 12 & $\mathrm{AB}$ & & & & $\sqrt{ }$ & & & $\sqrt{ }$ & & & & & $\checkmark$ & & & & $\checkmark$ \\
\hline 13 & AFR & & & & $\sqrt{ }$ & & & $\checkmark$ & & & $\checkmark$ & & & & & $\checkmark$ & \\
\hline $\begin{array}{c}\mathbf{J M} \\
\mathbf{L}\end{array}$ & & $\mathbf{0}$ & 2 & 7 & 4 & $\mathbf{0}$ & 2 & 6 & 5 & 1 & 2 & 5 & 5 & $\mathbf{0}$ & 2 & 6 & 5 \\
\hline
\end{tabular}


Vol. 1 No.3 Desember 2019

Ensiklopedia Education Review

http://jurnal.ensiklopediaku.org

Ket Penilaian:

\begin{tabular}{|c|c|c|c|c|}
\hline BB & Belum Berkembang & & 1 & $\begin{array}{l}\text { Mendengarkan cerita dengan penuh } \\
\text { perhatian }\end{array}$ \\
\hline MB & Mulai Berkembang & & 2 & $\begin{array}{l}\text { Melanjutkan/ Menyambung sebagian cerita } \\
\text { yang telah didengarnya }\end{array}$ \\
\hline $\mathrm{SH}$ & $\begin{array}{l}\text { Berkembang } \\
\text { Harapan }\end{array}$ & Sesuai & 3 & Mengulang kalimat yang telah di d \\
\hline & Berkembang Sanga & Baik & & Berani bertanya secara sederhana \\
\hline
\end{tabular}

Berdasarkan hasil Pengamatan yang telah dilakukan pada siklus II Pertemuan I dan 2 dapat dilihat secara umum perkembangan bahasa anak telah meningkat.Untuk lebih jelasnya tentang perkembangan bahasa anak dengan permainan menyambung cerita pada siklus II dapat dilihat pada garafik 2 berikut ini:

Grafik: 2

\section{Meningkatkan Perkembangan Bahasa Anak dengan Permainan Menyambung cerita Di kelompok B TK Negeri 01 Sangir jujuan Kecamatan Sangir Jujuan Kabupaten Solok Selatan}

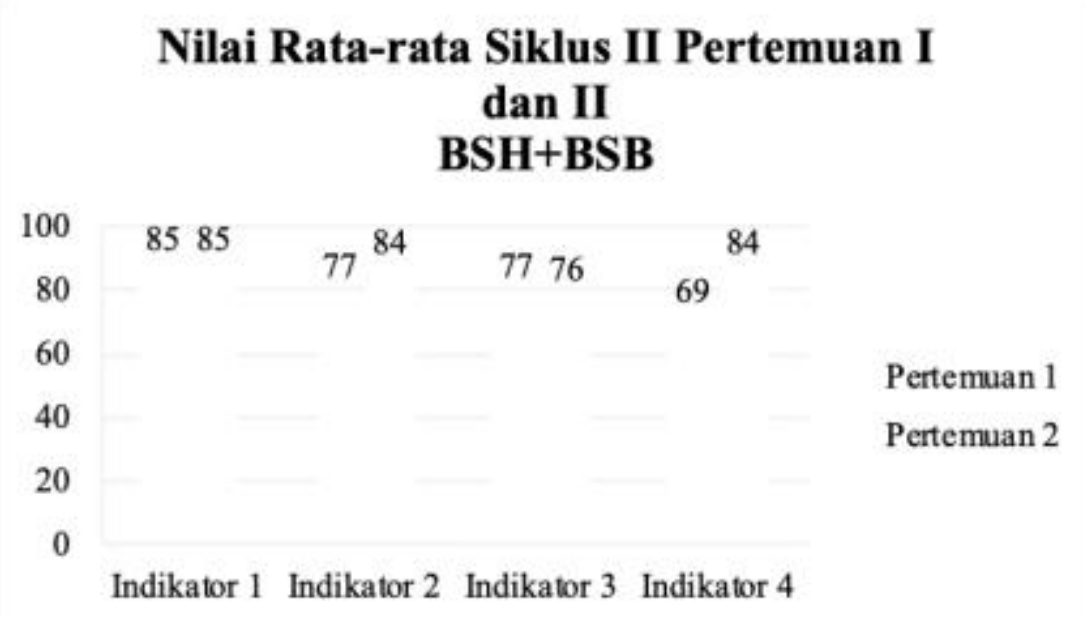

Dari grafik 2 di atas dapat disimpulkan secara umum perkembangan bahasa anak dari siklus I pertemuan II meningkat di siklus II dan telah mencapai indikator keberhasilan yang ditetapkan yaitu $75 \%$ atau lebih, anak memperoleh BSH dan BSB. Dengan telah dicapainya indikator keberhasilan, penelitian yang telah dilakukan di kelompok B TK Negeri 01 Sangir jujuan Kecamatan Sangir JujuanKabupaten Solok Selatan. Maka Penggunaan Permainan Menyambung cerita terbukti dapat meningkatkan perkembangan bahasa anak sehingga penelitian ini dihentikan pada siklus II.

Untuk membuktikan perkembangan bahasa anak meningkat, aspek anak membandingkan kondisi awal dengan indikator keberhasilan yaitu: Nilai rata- rata siklus II pertemuan 2 di kurang dengan nilai rata -rata kondisi awal $(82,25 \%-15 \%=$ $67,25 \%)$. Berdasarkan hasil Pengamatan yang diperoleh dari siklus I dan siklus II dapat dilihat peningkatan perkembangan bahasa anak dengan Permainan Menyambung Cerita Pada grafik 3 berikut ini: 


\section{Grafik: 3}

Perkembangan Bahasa anak dengan Permainan Menyambung Cerita

Dari Siklus I ke Siklus II

\section{Meningkatkan Perkembangan Bahasa \\ Anak \\ dari Siklus I ke Siklus II}

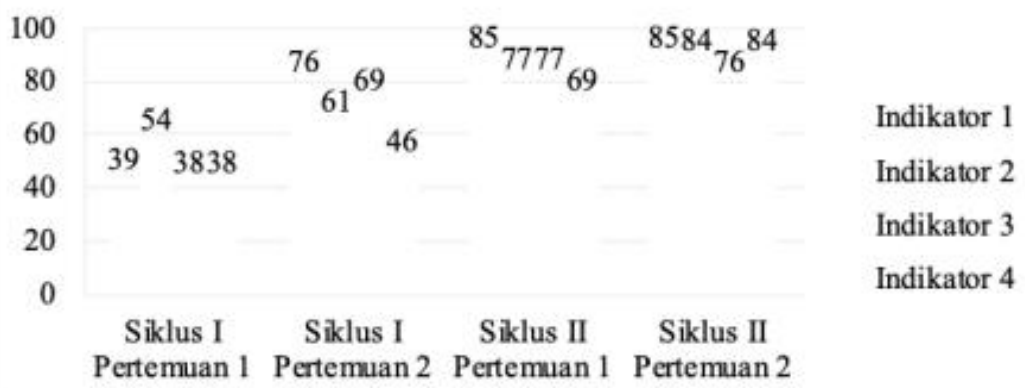

Berdasarkan grafik 3 di atas dapat dilihat secara jelas peningkatan persentase indikator 4 perkembangan bahasa anak pada siklus I pertemuan pertemuan pertama $38 \%$ dan pertemuan kedua $46 \%$ meningkat pada siklus II pertemuan pertama menjadi $69 \%$, pada pertemuan kedua siklus II perkembangan bahasa anak meningkat lagi menjadi $84 \%$.

\section{Penutup}

Pada pembahasan menyambung cerita ini mengalami peningkatan dari siklus I ke siklus II menjadi 85\%. Pada siklus II perkembangan bahasa anak telah meningkat dan telah mencapai indikator keberhasilan. Dari hasil penelitian ini dapat dinyatakan bahwa melalui permainan menyambung cerita dapat meningkatkan perkembangan bahasa anak yang telah mencapai indikator kinerja yang ditetapkan yaitu $75 \%$ atau lebih anak telah mendapat bintang tiga (BSH) atau bintang empat (BSB) yang mengacu pada PERMENDIKNAS. No 58 tahun 2009 dan penelitian ini dihentikan.

\section{Daftar Pustaka}

Agus, Wibowo. 2012. Strategi Membangun Karakter Anak Usia Dini. Yogyakarta: Pustaka Pelajar.

Anwar. 2009. Pendidikan Anak Usia Dini Panduan Praktis bagi Ibu dan Calon Guru. Bandung: Alfabeta.

Arikunto (2008:16). Langkah Mudah Penelitian Tindakan Kelas Profesi Guru. Jakarta:RajaGrafindo Persada.

Ayu, Shinta. 2014. Segudang game edukatif mengajara, Jogjakarta. DIVA Press.

Santosa, Vincentius Endy. 2008. 100 Permainan Kreatif untuk Outbond dan Training.

Yogyakarta: CV Andi Offset.

Sumanto. 2014. Psikologi Perkembangan; fungsi dan teori. Yogyakarta: CAPS.

Susanto, Ahmad. 2011. Perkembangan Anak Usia: Pengantar Dalam Berbagai Aspeknya. Jakarta: Kencana.

Undang-Undang No. 20 Tahun 2003 tentang Sistm Pendidikan Nasional.

Vigotsky". Online. http://valmband.multiply.com/journal/item/11?\&show_interstit $\mathrm{Ial}=1 \& \mathrm{u}=\% 2 F j o u r n a 1 \% 2 F i t e m$. Diakses 13 November 2015.

Wahyu, Anggi Rani. 2011. Maksimalisasi Media dalam Pembelajaran. Jakarta: Rosda Karya.

Yusuf, Syamsu. 2011. Perkembangan Peserta didik. Jakarta: Rajawali Pers. 